\title{
Adaptation of red clover to the long day environment
}

\author{
SEPPO PULLI \\ Agricultural Research Centre \\ Dept. of Plant Breeding \\ $S F-31600$ Jokioinen
}

\begin{abstract}
Five known varieties and five local strains of red clover from the latitudes 60 to $66^{\circ} \mathrm{N}$ were studied in greenhouse conditions. Photoperiods during the growing period were 12,16 and $20 \mathrm{~h}$ day, night temperatures $17^{\circ}$ and $14^{\circ} \mathrm{C}$ and light intensity $21.2 \mathrm{klux}$. The plants were cut three times. Flowering, height development and shoot DM yield were assessed at each harvest. The number of shoots and leaves per plant and leaf area per plant were determined at the second harvest and root size at the third harvest. After the second harvest one replicate of each strain under the three light regimes was placed at $+4^{\circ} \mathrm{C}$ under an 8 -h light regime at 10 klux for 26 days. For assessment of plant response to hardening conditions, chemical analyses were performed on roots for TNC, long-chain fatty acids and proline.

The study showed that the adaptation of red clover to certain daylength conditions influences plant behaviour with respect to its growth, development and hardening. The present study on daylength and growth together with developmental and chemical analysis are useful for breeding.
\end{abstract}

Index words: Red clover, daylength, hardening

\section{Introduction}

The genus Trifolium includes approximately 250 annual and perennial species, commonly called clovers, which are native to the humid, temperate regions of the world. About 25 species are of significance as food for grazing animals and of these, about 10 are agriculturally important (Evans 1976).

The centre of diversity of clovers is the eastern Mediterranean region where the main limiting factor is summer drought (COOPER
1965). Clovers are either winter annuals surviving the dry season as seeds or if perennial, show summer dormancy. Most adapted populations from this region demonstrate the ability to grow at low temperatures and low light intensities. In contrast, local varieties from northern Europe display a different seasonal pattern of growth. These clovers are perennial, with considerable frost resistance and winter dormancy. Leaf production at low temperatures and low light intensities is poor, but increases considerably during the long day and 
abundant radiation of the northern growing season.

According to the earliness of flowering (Williams 1927), number of cuttings (PIETERS 1928) and number of internodes at the onset of flowering (HAwKINS 1952), red clover can be classified into three clones of adaptability: a) early flowering red clover under a system of one year leys with two or more cuts per year; b) late flowering single-cut type red clover; and, c) intermediate red clover of the two main types. VALLE and GARRISON (1959), however, have concluded that the behaviour of late flowering single-cut clover approaches that of early type if late type seed production is carried out in areas south of its origin.

The early red clover produces shoots with flowers regularly during the year of seeding (JulÉn 1959). Plant development is rapid and regrowth after cuttings abundant. As a result of fast stem formation, the leaf rosette of the root crown and the whole root system remain underdeveloped. An open leaf rosette provides inadequate protection to the root crown against frost and also the accumulation of root carbohydrates necessary to winter survival is insufficient. Due to the lack of winter survival cultivation of the early red clover is concentrated in southern Europe.

The mid-late red clover is considered to be an intermediate of the early and late clover types. It is grown in the areas between those of the two main types, in central Europe and southern Scandinavia from the latitude $50^{\circ}$ to $60^{\circ} \mathrm{N}$ (JULÉN 1959). Red clover grown in North America is mainly classified into this group. Despite abundant flowering during the seeding year, mid-late red clover is productive in the stand for two or three years in the areas where it is adapted. Danish and southern Swedish mid-late strains behave mainly as late types do, but are able to flower during the seeding year if growing conditions are favourable enough.

Late red clover is characterized by a very slow pace of early development. Flowering of the late type is suppressed during the year of seeding but root development is strong and leaf rosette formation abundant. Flowering of the late type occurs for the first time during the second growing season, but only once, and four weeks later than flowering of the early types. Late red clover is characteristic to Nordic growing conditions where the stand is cut once per season and the aftermath is pastured (JULÉN 1959, 1977). Regrowth is generally modest, at best, but the accumulation of carbohydrates into the roots is strong and overwintering ability better than that of early types due to a closed type of rosette around the root crown, and high level of food reserved in the roots. Late red clover has the best adaptation in the central and northern parts of Scandinavia and northern Russia.

The late type of red clover grown in Finland can be divided into two main groups: the tall, relatively late flowering clover of southern Finland and the low, earlier flowering type of northern Finland. The northern type has a very closed leaf rosette around the root crown and excellent adaptation to the long snow cover time (RAVANTTI 1961). In addition, intermediates of these two main types are also grown in Finland. The red clover varieties Tepa (4n), Venla (2n) and Jokioinen (2n) belong to the tall type of southern Finland, and the Swedish local variety Bjursele belongs to the low type of northern areas. The Swedish breed Björn can be classified as an intermediate of these two. In addition, several local strains are also grown in Finland. Local strains can be characterized by their adaptation to a rather specific environment, but when moved to an another environment their productivity is lowered significantly (RAVANTTI 1980).

JuLÉn (1977) conculded that all red clovers are physiologically long day plants but the daylength requirements for flowering vary according to the geographical adaptation of various strains. Flowering of the early red clover is accelerated and regrowth improved, but overwintering is weakened when it is moved from short day conditions to the long day environment. Correspondingly, the northern late type of clover, when moved to the short day, 
loses its regrowth abilities. However, overwintering is improved which, in turn, influences the yield of the succeeding year. The same trend can be observed among diploid and tetraploid strains.

The breeding objective of combining the abundant regrowth of the early type of red clover with the good overwintering of the late type is impossible according to JULÉN (1977) because both characteristics are completely controlled by daylength. According to this concept, the breeding of red clover should be carried out separately in each daylength region. True progress in the breeding of red clover will be possible when more detailed information about the physiological behaviour of red clover becomes available.

The aim of this study was to survey, for the purposes of breeding, certain adaptation characters of five red clover varieties and five local red clover strains grown in Finland. The experimental parameters of the study were daylength behaviour and the hardening features of the plants in relation to daylength.

The parameters measured characterizing daylength behaviour of the plants were: dry matter accumulation of shoots and roots, plant height and LAI development, leaf and shoot formation, and flowering and hardening of the plants. The parameters measured for the hardening process were total nonstructural carbohydrates, long-chain fatty acids and prolin production.

\section{Materials and methods}

Five known varieties and five local strains of red clover from the latitudes $60^{\circ}$ to $66^{\circ} \mathrm{N}$ (Fig. 1) were studied in a greenhouse at the Agricultural Research Centre under different light regimes to determine adaptative behaviour of the plants. Varieties Jokioinen $(2 n)$, Venla (2n) and Tepa (4n) represented breeds of southern Finland. The Swedish variety Björn ( $2 n)$ is an intermediate breed from $63^{\circ} \mathrm{N}$ latitude, and the Swedish local variety Bjursele (2n) represented the northern most type of red clover from the latitude $66^{\circ} \mathrm{N}$. The

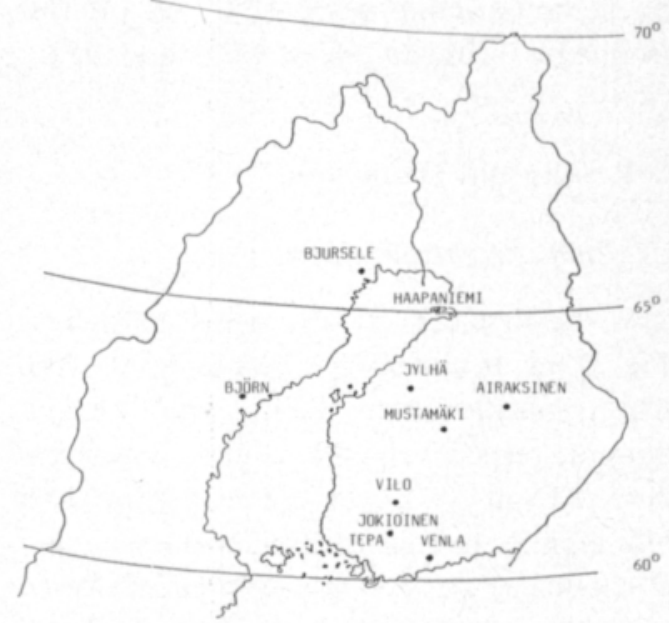

Fig. 1. Origin or location of the studied red clover strains.

Finnish local strain Vilo is cultivated in southern Finland, local strains Mustamäki, Jylhä and Airaksinen in central Finland and Hailuoto in northern Finland (Fig. 1). Genetic origins of the local strains were unknown, but they were known to be cultivated $\geq 20$ years in the same place.

Inoculated seeds were planted in 10-litre pots filled with a fertilized and limed mixture $(1: 1)$ of sand and peat. Photoperiods were 12,16 and $20 \mathrm{~h}$, day, night temperatures 17 and $14^{\circ} \mathrm{C}$, and light intensity 21.2 klux. First harvest was taken 132 days after seeding (Table 1), second harvest 47 days later and third harvest 45 days after the second. Flowering and plant height development were assessed at each harvest. The number of shoots and leaves per plant and leaf area per plant were also determined at the second harvest and root size at the third harvest. Dry matter yield of the plants was determined at each harvest. After the second harvest one replicate of each strain under the three light regimes was placed at $+4^{\circ} \mathrm{C}$ temperature under an 8 -h light regime of 10 klux for 26 days. For assessment of plant response to the hardening conditions chemical analyses were performed on roots for TNC, long-chain fatty acids and proline. Storage carbohydrates were analyzed according to Sмітн (1969), long-chain fatty acids by 
the method of HiLtunEN et al. (1979) and free proline by the technique of CHINARD (1952).

\section{Results and Discussion}

\subsection{Plant height development}

At the first harvest, average stand height (Fig. 2) was 16 and $67 \%$ higher under the 20-h light regime than under the 16-h and 12-h light regimes, respectively. Plant growth was enhanced from the beginning under the 20-h light regime. In contrast, under the 16-h and 12-h light regimes height development slowed down after the first harvest and the plants began to prepare for winter. At the second harvest (Fig. 3), average stand height was 49 and $65 \%$ higher in the 20 -h group than in the 16-h and 12-h groups, respectively. In each group, strains of northern origin lost their apical dominance earlier than did strains of southern origin. Height development was lowest in Bjursele, the northernmost variety. From the local strains, the northernmost, Hailuoto, had the earliest cessation in height development for all light regimes.
Table 1. Experimental design and timetable.
Varieties:

1. Venla $(2 n)$

2. Jokioinen $(2 n)$

3. Björn (2n)

4. Bjursele (2n)

5. Tepa $(4 n)$

6. Vilo/Lempảălä $(2 n)$

7. Jylhä/Kaustinen $(2 n)$

8. Mustamăki/Saarijärvi (2n)

9. Airaksinen/Maaninka (2n)

10. Haapaniemi/Hailuoto (2n)

16.2. Seeding

Stand height measurements

Growth analysis

Onset of flowering (20-h)

Ist cut

Onset of flowering after 1st cut (20-h)

2nd cut

Hardening

Chemical analysis

3rd cut
Daylengths

1. $12 \mathrm{~h}$

2. $16 \mathrm{~h}$

3. $20 \mathrm{~h}$
Replicates: 4

Age of stand: 26 days

60 "

69 "

$132 m$

158 ”

179 "

189 "

$215 "$

$224 "$

The study clearly showed that the long day about equally promoted plant height development of all strains observed. The results support the observations of Schulze (1957), Umaerus (1963a) and TANASCH (1979). A corresponding result was found in the develop-
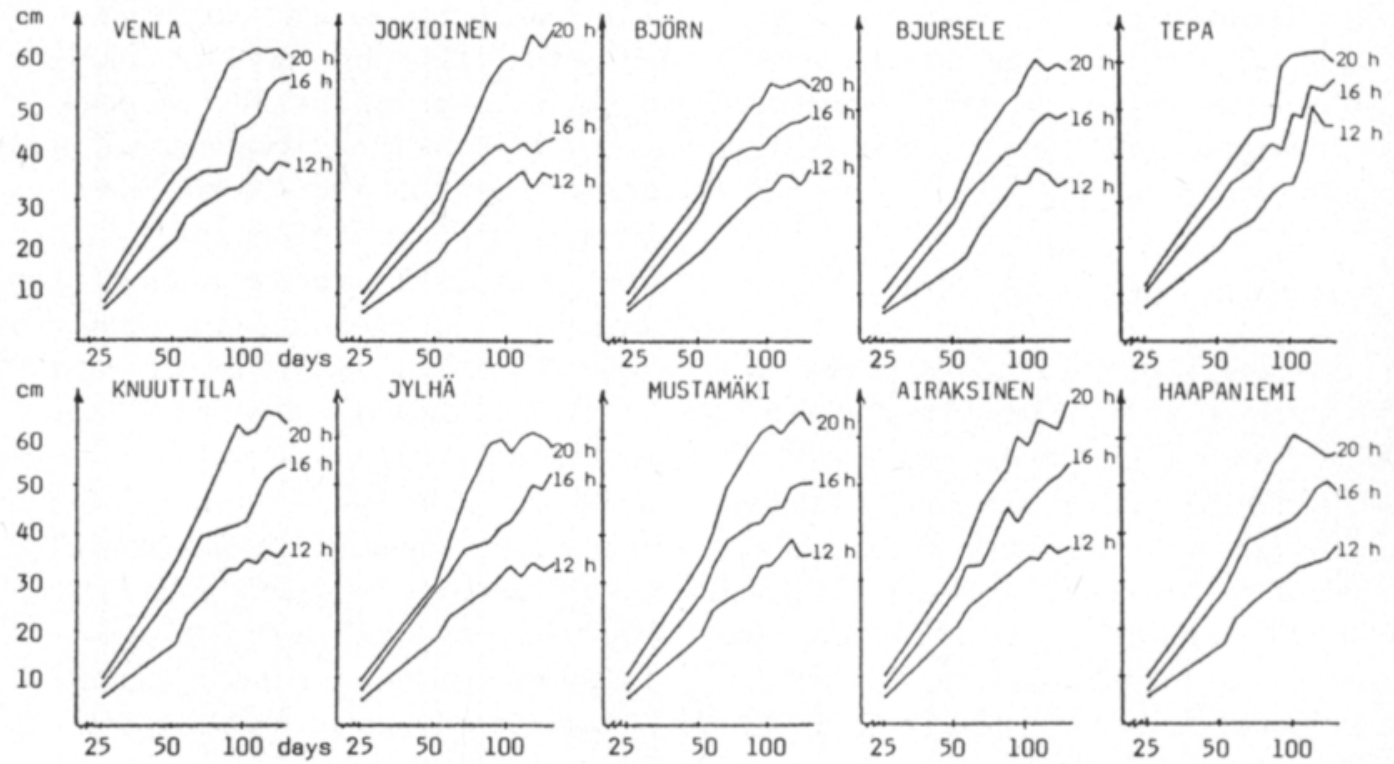

GROWING TIME, DAYS

Fig. 2. Height development $(\mathrm{cm})$ of red clover strains at different daylengths from seeding to the first cut. 

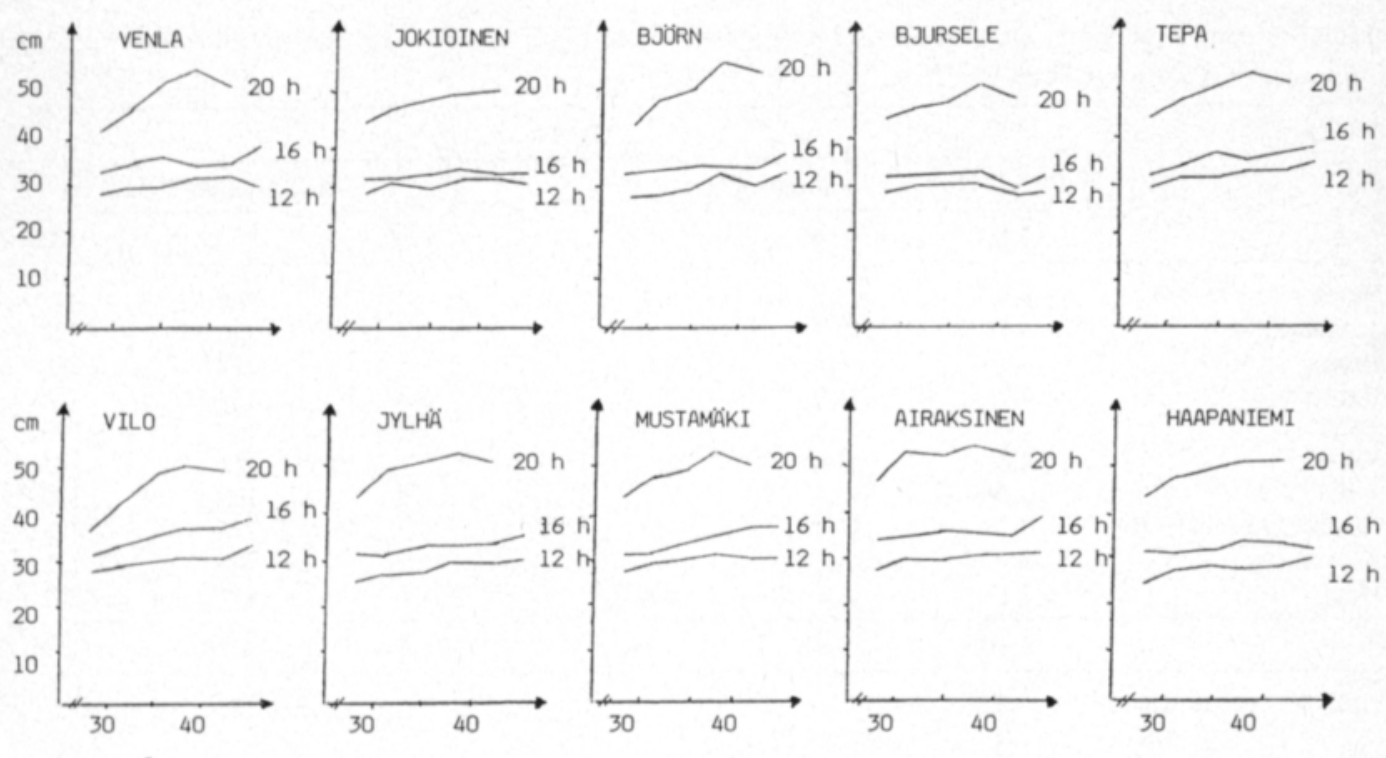

GROWING TIME, DAYS FROM 1. CUT

Fig. 3. Height development $(\mathrm{cm})$ of red clover strains between the first and the second cut (flowering) at different daylengths.

ment of the plants after the first harvest. However, height development in 16-h and 12-h light regimes was effectively prevented after the first cut thus showing the good adaptability of the strains studied to long day conditions. In shorter days apical dominance for the generative phase was lost and the plants prepared for winter. The results closely followed the observation of UMAERUS (1963b).

\subsection{Shoot formation and leaf area development}

Shooting ability and leaf development of the plants were studied at age 60 days, when the initiation of flowering during long day treatment was observed and again at the second harvest.

At age 60 days the number of shoots per plant was equal among the three daylength groups (Table 2). Of the individual strains, the northern types Bjursele and Jylhä showed the best adaptability to long day conditions introducing the most shoots during a 12-h day- length. Later development in the shooting ability of the strains measured at the second harvest (Table 3 ) showed that the longest photoperiod promoted the least shoots, suggesting the lowest winterhardiness for the plants among the three light regimes. The best shooting development in the long day group was in Bjursele indicating its good overwintering abilities.

Table 2. Number of shoots per plant of red clover varieties (V) grown 60 days at 12,16 and $20 \mathrm{~h}$ daylengths (D).

\begin{tabular}{lcccc}
\hline Variety (V) & \multicolumn{4}{c}{ Daylength (D) } \\
\cline { 2 - 5 } & $12 \mathrm{~h}$ & $16 \mathrm{~h}$ & $20 \mathrm{~h}$ & Avg. \\
\hline Venla & 2,4 & 1,6 & 1,5 & 1,8 \\
Jokioinen & 2,2 & 1,4 & 2,2 & 2,0 \\
Björn & 2,1 & 2,0 & 2,4 & 2,2 \\
Bjursele & 2,8 & 1,8 & 2,4 & 2,3 \\
Tepa & 1,8 & 2,2 & 1,4 & 1,7 \\
Vilo & 2,2 & 2,0 & 2,4 & 2,2 \\
Jylhă & 2,8 & 2,0 & 2,4 & 2,4 \\
Mustamäki & 2,3 & 2,1 & 1,9 & 2,1 \\
Airaksinen & 1,9 & 2,3 & 2,1 & 2,1 \\
Haapaniemi & 2,2 & 2,2 & 2,4 & 2,3 \\
\hline & 2,2 & 2,0 & 2,1 & 2,1 \\
\hline
\end{tabular}


Table 3. Number of shoots and leaf area $\left(\mathrm{cm}^{2}\right)$ per plant of red clover strains (V) in the second cut grown at 12 , 16 and $20 \mathrm{~h}$ daylengths (D).

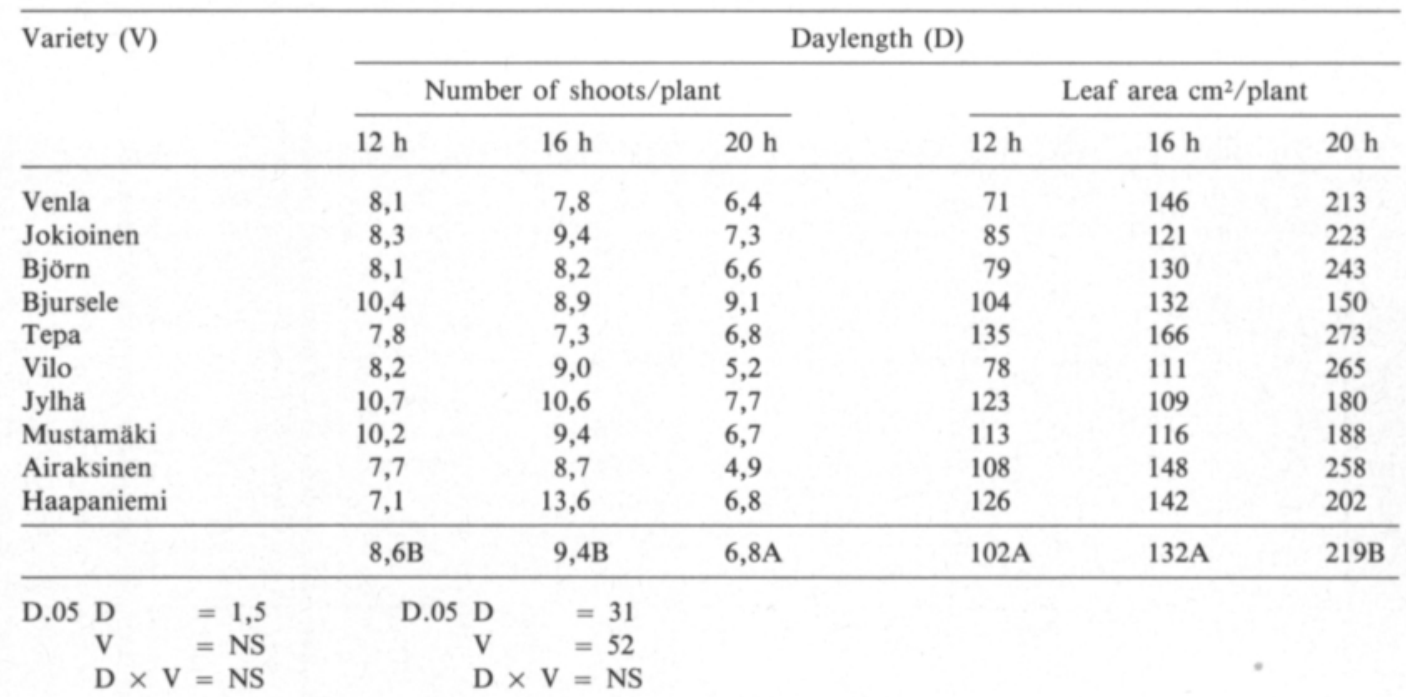

Leaf number per plant at age 60 days (Table 4) was equal among the three groups, but the northernmost strains tended to produce more leaves in both the 12 -h and the 20 -h groups. Long photoperiods during early development increased both total leaf areas and the size of individual leaves (Table 5). After further development under the 20 -h light regime (Table 3), total leaf areas were smaller

Table 4. Number of leaves per plant of red clover varieties (V) grown 60 days at 12,16 and $20 \mathrm{~h}$ daylengths (D).

\begin{tabular}{lrccc}
\hline Variety (V) & \multicolumn{4}{c}{ Daylength (D) } \\
\cline { 2 - 5 } & $12 \mathrm{~h}$ & $16 \mathrm{~h}$ & $20 \mathrm{~h}$ & Avg. \\
\hline Venla & $9,4 \mathrm{a}$ & $7,0 \mathrm{a}$ & $7,0 \mathrm{ab}$ & $7,8 \mathrm{a}$ \\
Jokioinen & $8,6 \mathrm{a}$ & $9,1 \mathrm{a}$ & $10,7 \mathrm{abc}$ & $9,5 \mathrm{ab}$ \\
Björn & $9,4 \mathrm{a}$ & $9,2 \mathrm{a}$ & $8,2 \mathrm{abc}$ & $8,9 \mathrm{ab}$ \\
Bjursele & $11,6 \mathrm{a}$ & $9,6 \mathrm{a}$ & $14,7 \mathrm{c}$ & $12,0 \mathrm{c}$ \\
Tepa & $6,4 \mathrm{a}$ & $9,5 \mathrm{a}$ & $5,6 \mathrm{a}$ & $7,2 \mathrm{a}$ \\
Vilo & $8,9 \mathrm{a}$ & $8,9 \mathrm{a}$ & $9,4 \mathrm{abc}$ & $9,1 \mathrm{ab}$ \\
Jylhä & $13,2 \mathrm{a}$ & $10,4 \mathrm{a}$ & $13,2 \mathrm{bc}$ & $12,3 \mathrm{c}$ \\
Mustamäki & $9,3 \mathrm{a}$ & $8,2 \mathrm{a}$ & $7,8 \mathrm{abc}$ & $8,4 \mathrm{a}$ \\
Airaksinen & $8,4 \mathrm{a}$ & $8,5 \mathrm{a}$ & $8,6 \mathrm{abc}$ & $8,5 \mathrm{a}$ \\
Haapaniemi & $9,5 \mathrm{a}$ & $10,1 \mathrm{a}$ & $13,6 \mathrm{bc}$ & $11,1 \mathrm{bc}$ \\
\hline & $9,5 \mathrm{~A}$ & $9,1 \mathrm{~A}$ & $9,9 \mathrm{~A}$ & 9,5 \\
\hline
\end{tabular}

$\begin{aligned} \mathrm{D} .05 \mathrm{D} & =\mathrm{NS} \\ \mathrm{V} & =2,4 \\ \mathrm{D} \times \mathrm{V} & =7,5\end{aligned}$

in the northern varieties than in the southern ones and smallest in Bjursele.

With regard to breeding, an interesting finding was that in the long photoperiod shooting was minimal but leaf area was doubled compared to 12-h and 16-h treatments (Table 3). The strains Bjursele and Jylhä best displayed the northern behaviour described by JULÉN (1977). Their shooting dominated over the formation of leaf area. The local strain Vilo and the varieties Venla and Jokioinen followed the pattern of southern late red clover. The rest of the strains behaved more or less as intermediates. The tetraploid variety Tepa behaved independently from the diploid types but can be classified as an intermediate.

\subsection{Flowering behaviour of the strains}

At first flowering, initiation of blooming in the 20-h photoperiod was latest in Bjursele (Table 6). Local strains from central Finland exhibited a somewhat southern ecotype behaviour. In a 16-h daylength the onset of flowering of all strains was delayed significantly and none of the strains flowered in a 12-h daylength. Development in the number of the inflorescences of red clover strains from 
Table 5. Leaf area $\mathrm{cm}^{2} /$ plant and individual leaflet of red clover varieties (V) grown 60 days at 12,16 and $20 \mathrm{~h}$ daylengths (D).

\begin{tabular}{|c|c|c|c|c|c|c|}
\hline \multirow[t]{3}{*}{ Variety (V) } & \multicolumn{6}{|c|}{ Daylength (D) } \\
\hline & \multicolumn{3}{|c|}{$\mathrm{cm}^{2} /$ plant } & \multicolumn{3}{|c|}{$\mathrm{cm}^{2} /$ leaflet } \\
\hline & $12 \mathrm{~h}$ & $16 \mathrm{~h}$ & $20 \mathrm{~h}$ & $12 \mathrm{~h}$ & $16 \mathrm{~h}$ & $20 \mathrm{~h}$ \\
\hline Venla & 72 & 80 & 93 & 7,6 & 11,4 & 13,2 \\
\hline Jokioinen & 50 & 86 & 158 & 5,8 & 9,5 & 14,7 \\
\hline Björn & 56 & 97 & 110 & 6,0 & 10,5 & 13,4 \\
\hline Bjursele & 58 & 79 & 150 & 3,6 & 8,2 & 10,2 \\
\hline Tepa & 53 & 129 & 106 & 8,2 & 13,6 & 18,9 \\
\hline Vilo & 61 & 124 & 114 & 6,9 & 13,9 & 12,1 \\
\hline Jylhä & 89 & 99 & 124 & 8,3 & 9,5 & 9,4 \\
\hline Mustamäki & 58 & 81 & 74 & 6,2 & 9,9 & 9,5 \\
\hline Airaksinen & 58 & 99 & 118 & 6,9 & 11,6 & 13,7 \\
\hline \multirow[t]{2}{*}{ Haapaniemi } & 52 & 95 & 161 & 5,5 & 9,4 & 11,8 \\
\hline & $61 \mathrm{~A}$ & $97 \mathrm{AB}$ & $121 \mathrm{~B}$ & $6,4 \mathrm{~A}$ & $10,7 \mathrm{AB}$ & $12,2 \mathrm{~B}$ \\
\hline
\end{tabular}

$\begin{array}{rlrl}\mathrm{D} .05 \mathrm{D} & =54 & \mathrm{D} .05 \mathrm{D} & =5,7 \\ \mathrm{~V} & =\mathrm{NS} & \mathrm{V} & =\mathrm{NS} \\ \mathrm{D} \times \mathrm{V}=\mathrm{NS} & \mathrm{D} \times \mathrm{V}=\mathrm{NS}\end{array}$

seeding to the first cut at a 20 -h daylength (Fig. 4) showed the superiority of the strain Jylhä above the others.

The abundance of the inflorescences of red clover strains during the second flowering followed the pattern observed in the first flowering (Table 7). In a 16-h daylength no differences in abundance of flowering among the six flowering strains were observed (Table 8). None of the strains flowered in a 12 -h daylength during the study period.

Table 6. Beginning of flowering of red clover varieties in days from seeding at 20,16 and 12 hour daylengths.

\begin{tabular}{lccc}
\hline Variety (V) & \multicolumn{3}{c}{ Daylength (D) } \\
\cline { 2 - 4 } & $12 \mathrm{~h}$ & $16 \mathrm{~h}$ & $20 \mathrm{~h}$ \\
\hline Venla & 71 & 123 & - \\
Jokioinen & 71 & - & - \\
Björn & 83 & - & - \\
Bjursele & 88 & 106 & - \\
Tepa & 78 & 106 & - \\
Vilo & 78 & 123 & - \\
Jylhä & 69 & 123 & - \\
Mustamäki & 69 & 130 & - \\
Airaksinen & 69 & 123 & - \\
Haapaniemi & 74 & 130 & - \\
\hline & 75 & 121 & - \\
\hline
\end{tabular}

JuLÉN(1977) showed that southern European strains under constant illumination have the flower-formation ability already at the five-leaf stage, but the flower-bearing stems are weak. Northern types tend to stay in the rosette stage until the development of strong vegetative shoots. In addition to the observa-

Table 7. Flowering of red clover varieties (inflorescences $/ 45$ plants $)$ at $20 \mathrm{~h}$ daylength $(\mathrm{A}=$ in the first, $\mathrm{B}=$ in the second and $\mathrm{C}=$ in the third cut).

\begin{tabular}{lcccc}
\hline Variety (V) & \multicolumn{4}{c}{ Number of inflorescences/45 plants } \\
\cline { 2 - 5 } & $\mathrm{A}$ & $\mathrm{B}$ & $\mathrm{C}$ & $\begin{array}{c}\text { Total } \\
(\Sigma)\end{array}$ \\
\hline Venla & $54 \mathrm{a}$ & $27 \mathrm{a}$ & $25 \mathrm{ab}$ & 106 \\
Jokioinen & $26 \mathrm{a}$ & $17 \mathrm{a}$ & $10 \mathrm{a}$ & 53 \\
Björn & $30 \mathrm{a}$ & $24 \mathrm{a}$ & $10 \mathrm{a}$ & 64 \\
Bjursele & $38 \mathrm{a}$ & $29 \mathrm{a}$ & $9 \mathrm{a}$ & 76 \\
Tepa & $28 \mathrm{a}$ & $25 \mathrm{a}$ & $12 \mathrm{ab}$ & 65 \\
Vilo & $43 \mathrm{a}$ & $24 \mathrm{a}$ & $14 \mathrm{ab}$ & 81 \\
Jylhă & $125 \mathrm{~b}$ & $60 \mathrm{~b}$ & $33 \mathrm{~b}$ & 218 \\
Mustamäki & $43 \mathrm{a}$ & $36 \mathrm{ab}$ & $25 \mathrm{ab}$ & 104 \\
Airaksinen & $45 \mathrm{a}$ & $39 \mathrm{ab}$ & $23 \mathrm{ab}$ & 107 \\
Haapaniemi & $66 \mathrm{ab}$ & $29 \mathrm{a}$ & $29 \mathrm{ab}$ & 124 \\
\hline & 47 & 31 & 19 & \\
\hline
\end{tabular}

D. 05 varieties (V) $A=64$
"
$\mathrm{B}=29$
$"$
$\mathrm{C}=21$ 


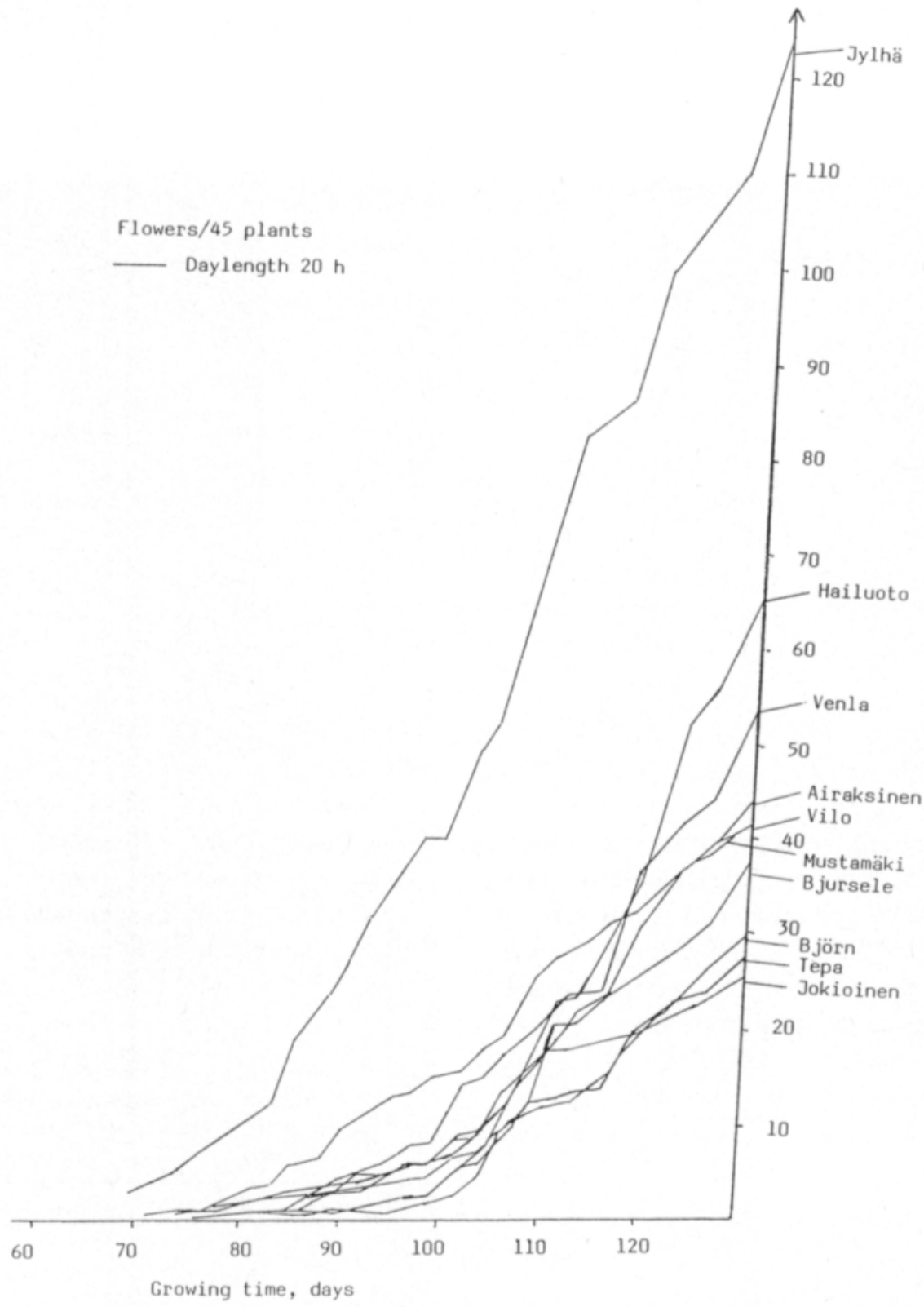

Fig. 4. Development of the number of inflorescences of red clover strains from seeding to the first cut at $20 \mathrm{~h}$ daylength.

tions of Julen, Umaerus (1963b) concluded that the more that daylength exeeds the minimum requirements of a plant, the faster its development will be from the vegetative phase to flowering. If available daylength significantly exceeds that required, red clover will have rapid flower development and the development of stems and leaves will remain low. In this study, the only strain of a distinctly northern ecotype was Bjursele, as was shown by the abundance and timing of its flowering. A very interesting behaviour was shown by the local strain Jylhä from central Finland. It had an early and abundant flowering in all three long day flowerings but flowering activity was slight at shorter daylengths. 
Table 8. Flowering of red clover varieties (V) (inflorescences $/ 45$ plants $)$ at $16 \mathrm{~h}$ daylength $(A=$ in the first, $\mathrm{B}=$ in the second and $\mathrm{C}=$ in the third cut).

\begin{tabular}{|c|c|c|c|c|}
\hline \multirow[t]{2}{*}{ Variety (V) } & \multicolumn{4}{|c|}{ Number of inflorescences $/ 45$ plants } \\
\hline & A & B & $\mathrm{C}$ & 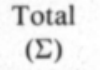 \\
\hline Venla & 1,0 & 0,3 & - & 1,3 \\
\hline Jokioinen & - & 0,3 & - & 0,3 \\
\hline Björn & - & - & - & - \\
\hline Bjursele & 0,8 & - & - & 0,8 \\
\hline Tepa & 3,5 & - & - & 3,5 \\
\hline Vilo & 0,3 & 0,3 & - & 0,6 \\
\hline Jylhä & 0,3 & - & - & 0,3 \\
\hline Mustamäki & 0,3 & 0,3 & - & 0,6 \\
\hline Airaksinen & 1,0 & 0,3 & - & 1,3 \\
\hline Haapaniemi & 1,3 & 0,3 & - & 1,6 \\
\hline
\end{tabular}

Table 9. Dry matter yield g/pot of red clover varieties in the first cut grown 132 days at 12, 16 and $20 \mathrm{~h}$ daylengths (D).

\begin{tabular}{lllll}
\hline Variety (V) & \multicolumn{4}{c}{ Daylength (D) } \\
\cline { 2 - 5 } & 12 h & 16 h & 20 h & Avg. \\
\hline Venla & 35,9 & 77,3 & 142,1 & 85,1 \\
Jokioinen & 31,7 & 65,5 & 125,0 & 74,0 \\
Björn & 37,3 & 69,7 & 128,7 & 78,6 \\
Bjursele & 32,0 & 61,6 & 117,8 & 70,4 \\
Tepa & 37,7 & 79,5 & 122,3 & 79,8 \\
Vilo & 32,9 & 57,3 & 129,5 & 73,2 \\
Jylhă & 29,1 & 69,9 & 150,0 & 83,0 \\
Mustamăki & 41,8 & 59,3 & 134,2 & 78,4 \\
Airaksinen & 35,1 & 73,3 & 124,9 & 77,7 \\
Haapaniemi & 29,7 & 74,0 & 131,0 & 78,2 \\
\hline & $34,3 \mathrm{~A}$ & $68,7 \mathrm{~B}$ & $130,5 \mathrm{C}$ & 77,9 \\
\hline
\end{tabular}

$\begin{aligned} \mathrm{D} .05 \mathrm{D} & =5,8 \\ \mathrm{~V} & =\mathrm{Ns} \\ \mathrm{D} \times \mathrm{V} & =\mathrm{Ns}\end{aligned}$

However, the shoot and leaf formation of Jylhä followed the pattern of the northern type of red clover. All strains studied showed the growth pattern of one-cut red clover although other northern strains, with the exception of Bjursele, were somewhat less adaptable to long photoperiods and possessed some features of southern origin.
Table 10. Dry matter yield g/pot of red clover varieties (V) in the second cut grown 179 days at 12 , 16 and $20 \mathrm{~h}$ daylengths (D).

\begin{tabular}{|c|c|c|c|c|}
\hline \multirow[t]{2}{*}{ Variety (V) } & \multicolumn{4}{|c|}{ Daylength (D) } \\
\hline & $12 \mathrm{~h}$ & $16 \mathrm{~h}$ & $20 \mathrm{~h}$ & Avg. \\
\hline Venla & $18,4 \mathrm{a}$ & $23,5 \mathrm{a}$ & $42,4 \mathrm{ab}$ & $29,1 \mathrm{ab}$ \\
\hline Jokioinen & $18,6 a$ & $23,2 \mathrm{a}$ & $50,2 \mathrm{ab}$ & $30,7 \mathrm{ab}$ \\
\hline Björn & $17,9 \mathrm{a}$ & $25,5 \mathrm{a}$ & $47,5 \mathrm{ab}$ & $30,3 \mathrm{ab}$ \\
\hline Bjursele & $18,9 \mathrm{a}$ & $24,0 \mathrm{a}$ & $52,7 \mathrm{~b}$ & $31,8 \mathrm{ab}$ \\
\hline Tepa & $20,0 \mathrm{a}$ & $29,3 a$ & $56,9 \mathrm{~b}$ & $35,4 \mathrm{~b}$ \\
\hline Vilo & $16,1 \mathrm{a}$ & $21,9 \mathrm{a}$ & $26,9 \mathrm{a}$ & $21,6 \mathrm{a}$ \\
\hline Jylhă & $18,1 \mathrm{a}$ & $23,9 \mathrm{a}$ & $60,0 \mathrm{~b}$ & $34,0 \mathrm{ab}$ \\
\hline Mustamäki & $23,2 \mathrm{a}$ & $23,7 \mathrm{a}$ & $53,7 \mathrm{~b}$ & $33,5 \mathrm{ab}$ \\
\hline Airaksinen & $20,9 a$ & $28,7 \mathrm{a}$ & $58,6 \mathrm{~b}$ & $36,0 \mathrm{~b}$ \\
\hline \multirow[t]{2}{*}{ Haapaniemi } & $15,8 \mathrm{a}$ & $23,9 a$ & $49,4 \mathrm{ab}$ & $29,7 \mathrm{ab}$ \\
\hline & $18,8 \mathrm{~A}$ & $24,7 \mathrm{~A}$ & $49,8 \mathrm{~B}$ & 31,1 \\
\hline $\begin{aligned} \mathrm{D} .05 \mathrm{D} \\
\mathrm{V} \\
\mathrm{D} \times \mathrm{V}\end{aligned}$ & $\begin{array}{l}8,3 \\
12,7 \\
24,3\end{array}$ & & & e \\
\hline
\end{tabular}

Table 11. Dry matter yield g/pot of red clover varieties (V) in the third cut grown 226 days at 12, 16 and $20 \mathrm{~h}$ daylengths (D).

\begin{tabular}{|c|c|c|c|c|}
\hline \multirow[t]{2}{*}{ Variety (V) } & \multicolumn{4}{|c|}{ Daylength (D) } \\
\hline & $12 \mathrm{~h}$ & $16 \mathrm{~h}$ & $20 \mathrm{~h}$ & Avg. \\
\hline Venla & 13,8 & 22,6 & 58,7 & $31,7 \mathrm{ab}$ \\
\hline Jokioinen & 16,5 & 22,5 & 56,0 & $31,7 \mathrm{ab}$ \\
\hline Björn & 13,8 & 22,6 & 53,6 & $30,0 \mathrm{ab}$ \\
\hline Bjursele & 17,3 & 22,7 & 52,0 & $30,6 \mathrm{ab}$ \\
\hline Tepa & 22,7 & 28,3 & 59,9 & $37,0 \mathrm{~b}$ \\
\hline Vilo & 9,7 & 19,7 & 50,5 & $26,6 a$ \\
\hline Jylhã & 12,3 & 21,9 & 60,2 & $31,5 \mathrm{ab}$ \\
\hline Mustamäki & 20,1 & 25,0 & 60,2 & $35,1 \mathrm{~b}$ \\
\hline Airaksinen & 13,8 & 25,9 & 62,6 & $34,1 \mathrm{ab}$ \\
\hline \multirow[t]{2}{*}{ Haapaniemi } & 13,1 & 22,4 & 55,4 & $30,3 \mathrm{ab}$ \\
\hline & $15,3 \mathrm{~A}$ & $23,3 \mathrm{~B}$ & $56,9 \mathrm{C}$ & 31,9 \\
\hline $\begin{aligned} & \text { D.05 } \mathrm{D} \\
& \mathrm{V} \\
& \mathrm{D} \times \mathrm{V}\end{aligned}$ & $\begin{array}{l}2,7 \\
8,1 \\
\text { Ns }\end{array}$ & & & \\
\hline
\end{tabular}

\subsection{Dry matter yields of shoots and roots}

\section{Dry matter yields of shoots}

Under the light regimes 12,16 and $20 \mathrm{~h}$, DM yields were in the ratio of 15:50:55 at the first harvest (Table 9), 20:26:54 at the second harvest (Table 10) and 16:24:60 at the third harvest (Table 11). The different ratios at the 
second and third harvests clearly show the northern origin of the red clover strains studied. There were no differences among the varieties at the first and third harvests, but at the second harvest the northern varieties and the tetraploid Tepa gave the highest yields as expected in view of their pace of growth and tetraploid character, respectively.

In the total yields of the three cuts (Table 12) under the light regimes 12,16 and $20 \mathrm{~h}$. DM yields were in the ratio of $15: 28: 27$. The ratio shows the importance of daylength to the DM development of red clover. Northern types benefit from the long period of illumination. In the 12 and $16 \mathrm{~h}$ daylengths there were no significant differences among varieties. The degree of adaptation among strains could be observed at a 20-h daylength, although only the southern strain Vilo and northern strain Jylhä showed the only significant differences.

\section{Root dry matter accumulation}

Root dry matter accumulation during the entire test period showed that root development was 59 and $66 \%$ lower in the 12-h groups than in the $16-\mathrm{h}$ and 20 -h daylength

Table 12. Total DM yield $\mathrm{g} /$ pot in three cuts of red clover varieties (V) grown at 12,16 and $20 \mathrm{~h}$ daylengths (D).

\begin{tabular}{|c|c|c|c|c|}
\hline \multirow[t]{2}{*}{ Variety (V) } & \multicolumn{4}{|c|}{ Daylength (D) } \\
\hline & $12 \mathrm{~h}$ & $16 \mathrm{~h}$ & $20 \mathrm{~h}$ & Avg. \\
\hline Venla & $67,3 a$ & $123,4 \mathrm{a}$ & $243,2 \mathrm{ab}$ & $144,6 \mathrm{ab}$ \\
\hline Jokioinen & $66,8 \mathrm{a}$ & $111,2 \mathrm{a}$ & $231,2 \mathrm{ab}$ & $136,4 \mathrm{ab}$ \\
\hline Björn & $69,0 \mathrm{a}$ & $117,8 \mathrm{a}$ & $229,8 \mathrm{ab}$ & $138,8 \mathrm{ab}$ \\
\hline Bjursele & $68,2 \mathrm{a}$ & $108,3 \mathrm{a}$ & $222,5 \mathrm{ab}$ & $133,0 \mathrm{ab}$ \\
\hline Tepa & $80,4 a$ & $137,1 \mathrm{a}$ & $239,1 \mathrm{ab}$ & $152,2 \mathrm{~b}$ \\
\hline Vilo & $58,7 \mathrm{a}$ & $98,9 a$ & $206,9 \mathrm{a}$ & $121,5 \mathrm{a}$ \\
\hline Jylhä & $59,5 \mathrm{a}$ & $115,7 \mathrm{a}$ & $270,2 b$ & $148,5 b$ \\
\hline Mustamäki & $85,1 \mathrm{a}$ & $108,0 \mathrm{a}$ & $248,1 \mathrm{ab}$ & $147,1 b$ \\
\hline Airaksinen & $69,8 \mathrm{a}$ & 127,9 & $246,1 \mathrm{ab}$ & $147,9 b$ \\
\hline \multirow[t]{2}{*}{ Haapaniemi } & $58,6 \mathrm{a}$ & $120,3 \mathrm{a}$ & $235,8 \mathrm{ab}$ & $138,2 \mathrm{ab}$ \\
\hline & $61,4 \mathrm{~A}$ & $116,9 \mathrm{~B}$ & $237,3 \mathrm{C}$ & 140,8 \\
\hline $\begin{aligned} & \text { D.05 } \mathrm{D} \\
& \mathrm{V} \\
& \mathrm{D} \times \mathrm{V}\end{aligned}$ & $\begin{array}{l}=12,5 \\
=24,5 \\
=47,0\end{array}$ & & & \\
\hline
\end{tabular}

groups, respectively (Table 13). Differences in root size among the varieties were smallest in the 12-h group and greatest in the 16-h group showing a varying degree of adaptability. In each daylength group root size was smallest in Bjursele due to genetic development. Bjursele has a clearly branched root system instead of the distinct tap root commonly found among clovers.

The relationship between the daylength and root size of an invidual root is well described by a second degree regression equation where (x) represents daylength and (y) equals root size (Fig. 5). In the equation $\mathrm{R}^{2}$ explained $70,1 \%$ of the daylength.

\section{$\mathrm{y}=-1.12+0.149 \mathrm{x}-0.0037 \mathrm{x}^{2}(\mathrm{~F}=$ $\left.31.67^{* * *}\right)$}

Although root size accounts only partly for differences in the overwintering of plants, the long day tends to favour root development in the natural conditions of long day and long winter.

\subsection{Effects of daylength on red clover hardening}

\section{Root carbohydrates in relation to hardening}

Chemical analysis of plants subjected to hardening after the second harvest showed

Table 13. Root dry matter weight g/root of red clover varieties (V) in the third cut grown at 12,16 and $20 \mathrm{~h}$ daylengths (D).

\begin{tabular}{lcccc}
\hline Variety (V) & \multicolumn{4}{c}{ Daylength (D) } \\
\cline { 2 - 5 } & $12 \mathrm{~h}$ & $16 \mathrm{~h}$ & $20 \mathrm{~h}$ & Avg. \\
\hline Venla & 0,14 & 0,27 & 0,38 & 0,26 \\
Jokioinen & 0,10 & 0,30 & 0,38 & 0,26 \\
Björn & 0,11 & 0,35 & 0,44 & 0,30 \\
Bjursele & 0,09 & 0,25 & 0,29 & 0,21 \\
Tepa & 0,15 & 0,26 & 0,46 & 0,29 \\
Vilo & 0,20 & 0,22 & 0,46 & 0,29 \\
Jylhä & 0,20 & 0,49 & 0,41 & 0,37 \\
Mustamäki & 0,08 & 0,20 & 0,31 & 0,20 \\
Airaksinen & 0,14 & 0,38 & 0,29 & 0,27 \\
Haapaniemi & 0,13 & 0,43 & 0,35 & 0,30 \\
\hline & 0,13 & 0,32 & 0,38 & 0,28 \\
\hline
\end{tabular}




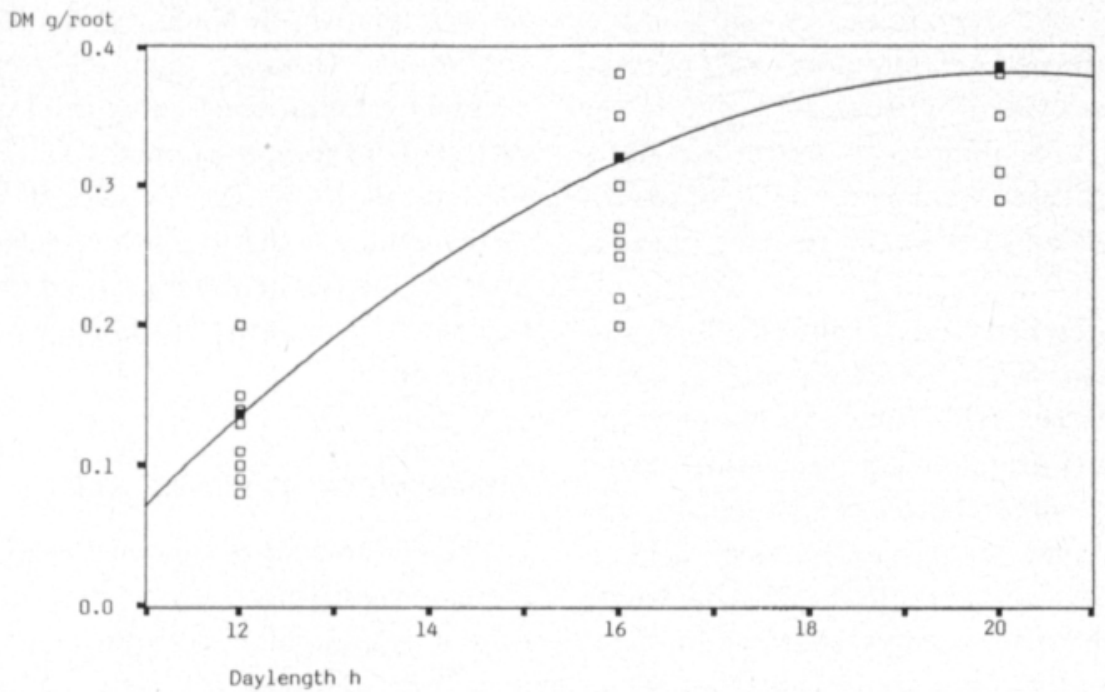

Fig. 5. Quadratic relationship between daylength and root size of an individual red clover root.

that carbohydrate accumulation by the roots, the indicator of hardening, was highest in plants grown under the 20 -h light regime (Table 14). TNC accumulation was highest for Tepa in the 12-h light regime group, Vilo in the 16-h group, and Bjursele in the 20-h group. Great differences in TNC accumulation among the clover strains were found in each of the three groups.

UMAERUS (1963a) has shown that daylength affects the overwintering of plants. It also influences flowering, onset and end of dormancy, as well as the chemical composition of various plant parts. JULÉN (1977) concluded that the early type of clover has a weak overwintering in long day conditions, and the late type adapted to long day conditions tends to have a deep dormancy also in the short day environment. This study agrees very well with that of Julén with respect to long day environment, but one-cut plants grown under short day behaved differently from the Julén model. The original long day plants hardened in the short day, and at low temperature conditions collected significantly less reserve food than the same plants grown in long day conditions and hardened in short day and low temperature conditions (Table 14).

\section{Fatty acid composition and hardening}

During hardening there are certain changes in the composition of long chain fatty acids. Hardening favours the increase of unsaturated fatty acids at the cost of saturated fatty acids (DE LA Roche et al. 1972, KUIPER 1970). Cell membranes dominated by unsatu-

Table 14. TNC (\% DM) of the roots of red clover strains (V) grown at 12, 16 and $20 \mathrm{~h}$ daylengths and hardened after the second cut for four weeks at $+4^{\circ} \mathrm{C}$ temperature and $8 \mathrm{~h}$ daylength.

\begin{tabular}{lllll}
\hline Variety (V) & \multicolumn{4}{c}{ Daylength (D) } \\
\cline { 2 - 5 } & $12 \mathrm{~h}$ & $16 \mathrm{~h}$ & $20 \mathrm{~h}$ & Avg. \\
\hline Venla & 16,2 & $16,7 \mathrm{bc}$ & $15,8 \mathrm{abc}$ & $16,2 \mathrm{c}$ \\
Jokioinen & $11,0 \mathrm{ab}$ & $18,7 \mathrm{de}$ & $17,6 \mathrm{~cd}$ & $15,7 \mathrm{ab}$ \\
Björn & $11,9 \mathrm{abc}$ & $18,1 \mathrm{cde}$ & $17,1 \mathrm{abcd}$ & $15,6 \mathrm{a}$ \\
Bjursele & $10,7 \mathrm{a}$ & $13,7 \mathrm{a}$ & $23,3 \mathrm{f}$ & $15,9 \mathrm{ab}$ \\
Tepa & $20,4 \mathrm{e}$ & $17,2 \mathrm{bcd}$ & $17,8 \mathrm{~d}$ & $18,5 \mathrm{~d}$ \\
Vilo & $13,4 \mathrm{c}$ & $21,0 \mathrm{f}$ & $17,4 \mathrm{bcd}$ & $17,3 \mathrm{c}$ \\
Jylhä & $10,0 \mathrm{a}$ & $19,8 \mathrm{ef}$ & $15,4 \mathrm{a}$ & $15,1 \mathrm{a}$ \\
Mustamäki & $15,6 \mathrm{~d}$ & $16,1 \mathrm{~b}$ & $15,6 \mathrm{ab}$ & $15,8 \mathrm{ab}$ \\
Airaksinen & $16,1 \mathrm{~d}$ & $17,5 \mathrm{bcd}$ & $21,9 \mathrm{e}$ & $18,5 \mathrm{~d}$ \\
Haapaniemi & $12,9 \mathrm{bc}$ & $17,4 \mathrm{bcd}$ & $21,6 \mathrm{e}$ & $17,3 \mathrm{c}$ \\
\hline & $13,8 \mathrm{~A}$ & $17,6 \mathrm{~B}$ & $18,3 \mathrm{~B}$ & 16,6 \\
\hline
\end{tabular}

$\begin{aligned} \text { D.05 D } & =3,4 \\ \mathrm{~V} & =1,0 \\ \mathrm{D} \times \mathrm{V} & =1,9\end{aligned}$


rated fatty acids tend to be less fragile at low temperatures and are thus more easily restored after stress caused by frost. In addition, the abundant availability of unsaturated fatty acids improves the semipermeability of the cell membranes and lowers the freezing point of cell sap.

The present study showed that the predominant long chain fatty acid in clover roots was linolic acid (Table 15). The more important fatty acid, linolenic acid, which correlates with winter hardiness in cereals, was present in minor quantities. Linolenic acid accumulation was highest in the 12-h daylength group. Under long day conditions linolenic acid content was highest in Bjursele indicating its good overwintering qualities and long day adaptation.

Fatty acid analysis clearly showed that all of the red clover strains studied had, in this respect, relatively low adaptability to long day conditions. Although there are great differences of opinion concerning the importance of fatty acid composition in winter hardiness (Willemot 1977, De LA Roche 1979), it seems apparent that the low content of linolenic acid in the hardening of red clover may be one of the reasons for damage due to low temperatures.

\section{Proline production in hardening}

The amino acid proline has been found to increase significantly under stress conditions caused by high salt concentration of drought, and high and low temperatures (STEWART 1981). LedDET and SchaEVERBEKE (1975) concluded that in low concentrations proline mainly has an osmotic effect, but in high concentrations under stress conditions proline has

Table 15. Fatty acid content (\%) of the roots of red clover strains (V) grown at 12, 16 and $20 \mathrm{~h}$ daylengths (D) and hardened after the second cut for four weeks at $+4^{\circ} \mathrm{C}$ temperature and $8 \mathrm{~h}$ daylength.

\begin{tabular}{|c|c|c|c|c|c|c|c|c|c|c|c|}
\hline Fatty acid & Venla & $\begin{array}{c}\text { Jokioi- } \\
\text { nen }\end{array}$ & Björn & $\begin{array}{l}\text { Bjur- } \\
\text { sele }\end{array}$ & Tepa & Vilo & Jylhä & $\begin{array}{l}\text { Musta- } \\
\text { mäki }\end{array}$ & $\begin{array}{c}\text { Airak- } \\
\text { sinen }\end{array}$ & $\begin{array}{l}\text { Haapa- } \\
\text { niemi }\end{array}$ & Avg. \\
\hline \multicolumn{12}{|l|}{ Daylength $12 h$} \\
\hline Palmitic acid $(16: 0)$ & 15,9 & 15,1 & 15,1 & 16,0 & 13,3 & 13,8 & 22,2 & 21,2 & 20,6 & 19,3 & 17,3 \\
\hline Stearic acid $(18: 0)$ & 1,7 & 2,3 & 1,8 & 2,4 & 1,6 & 1,8 & 2,6 & 2,1 & 2,2 & 2,0 & 2,1 \\
\hline Oleic acid $(18: 1)$ & 6,6 & 5,3 & 7,1 & 5,7 & 8,3 & 6,3 & 6,8 & 7,6 & 7,1 & 5,8 & 6,7 \\
\hline Linoleic acid $(18: 2)$ & 51,6 & 51,6 & 55,4 & 51,0 & 51,6 & 55,0 & 45,5 & 47,9 & 44,7 & 49,2 & 50,9 \\
\hline Linolenic acid $(18: 3)$ & 21,4 & 22,0 & 17,4 & 21,2 & 17,6 & 20,5 & 14,5 & 15,7 & 18,8 & 17,7 & 18,7 \\
\hline Arakidinic acid $(20: 0)$ & 0,9 & 1,2 & 1,0 & 1,1 & 0,9 & 0,8 & 1,8 & 1,6 & 1,6 & 1,7 & 1,3 \\
\hline Eikosadienic acid $(20: 2)$ & 0,5 & 0,6 & 0,3 & 0,8 & 0,3 & 0,3 & 0,8 & - & - & - & 0,4 \\
\hline Behenic acid $(22: 0)$ & 1,2 & 1,8 & 1,6 & 1,6 & 1,2 & 1,4 & 4,5 & 4,0 & 4,0 & 4,3 & 2,6 \\
\hline \multicolumn{12}{|l|}{ Daylength $16 h$} \\
\hline Palmitic acid (16:0) & 19,3 & 17,7 & 19,2 & 20,3 & 18,4 & 19,4 & 19,7 & 20,4 & 19,9 & 19,8 & 19,4 \\
\hline Stearic acid $(18: 0)$ & 2,0 & 2,1 & 2,1 & 2,0 & 1,9 & 1,9 & 1,9 & 1,9 & 1,9 & 1,9 & 2,0 \\
\hline Oleic acid $(18: 1)$ & 10,2 & 9,3 & 11,2 & 7,5 & 9,4 & 7,8 & 10,2 & 9,9 & 9,0 & 8,3 & 9,3 \\
\hline Linoleic acid $(18: 2)$ & 46,6 & 48,6 & 46,2 & 49,8 & 48,2 & 50,8 & 48,6 & 47,4 & 48,2 & 45,3 & 48,0 \\
\hline Linolenic acid $(18: 3)$ & 14,7 & 15,9 & 14,9 & 14,7 & 13,8 & 13,6 & 15,5 & 14,3 & 16,5 & 18,7 & 15,3 \\
\hline Arakidinic acid $(20: 0)$ & 1,7 & 1,4 & 1,5 & 1,1 & 1,2 & 1,3 & 1,0 & 1,3 & 1,1 & 1,2 & 1,3 \\
\hline Eikosadienic acid $(20: 2)$ & - & - & 0,3 & 0,3 & 0,5 & 0,1 & 0,1 & 0,2 & 0,1 & 0,4 & 0,2 \\
\hline Behenic acid $(22: 0)$ & 4,8 & 4,8 & 4,4 & 3,8 & 4,9 & 4,6 & 2,6 & 4,5 & 2,9 & 3,9 & 4,1 \\
\hline \multicolumn{12}{|l|}{ Daylength $20 \mathrm{~h}$} \\
\hline Palmitic acid $(16: 0)$ & 19,0 & 19,5 & 18,8 & 18,6 & 18,0 & 20,0 & 19,9 & 18,8 & 18,5 & 19,0 & 19,0 \\
\hline Stearic acid $(18: 0)$ & 1,6 & 1,6 & 1,6 & 1,6 & 1,7 & 1,5 & 1,7 & 1,5 & 1,7 & 1,7 & 1,6 \\
\hline Oleic acid $(18: 1)$ & 7,3 & 8,9 & 7,6 & 8,5 & 10,1 & 6,9 & 9,0 & 9,5 & 9,9 & 9,1 & 8,7 \\
\hline Linoleic acid $(18: 2)$ & 50,1 & 50,9 & 51,9 & 48,7 & 50,2 & 52,6 & 47,8 & 49,9 & 50,3 & 49,7 & 50,2 \\
\hline Linolenic acid $(18: 3)$ & 16,7 & 15,0 & 14,8 & 17,5 & 14,6 & 15,6 & 17,0 & 14,9 & 14,5 & 14,6 & 15,5 \\
\hline Arakidinic acid $(20: 0)$ & 1,2 & 1,0 & 1,1 & 1,1 & 1,0 & 0,8 & 1,2 & 1,2 & 1,0 & 1,2 & 1,1 \\
\hline Eikosadienic acid $(20: 2)$ & 0,2 & 0,2 & 0,5 & 0,3 & 0,7 & 0,3 & 0,1 & 0,3 & 0,2 & 0,3 & 0,3 \\
\hline Behenic acid $(22: 0)$ & 3,6 & 2,9 & 3,2 & 3,2 & 3,6 & 2,3 & 3,4 & 3,6 & 3,8 & 4,1 & 3,4 \\
\hline
\end{tabular}


a special mode of action. A significant role of proline is to protect the thylacoid membranes of plants against activity losses due to frost. The protection mechanism relies on the production of productive collagens. Proline production is stimulated by abscicic acid through the synthesis of glutamic acid (STEWART 1980). The physiological action of proline classifies it as a cryoprotector.

Study of proline showed that red clover has a different protection mechanism against frost depending on the daylengths to which the strains are subjected before the hardening period (Table 16). The protection mechanism is most effectively developed the longer the daylength is. All red clover strains studied reacted to the daylength, but the most distinct proline production was observed in the northern variety Bjursele and the local strain Vilo from southern Finland. According to the results, the two red clover strains have the best protection against frost, as observed also in natural conditions.

\section{Conclusions}

The study presented two hypotheses: 1) Adaptation of red clover to a certain daylength condition influences plant behaviour with respect to its growth and development and to hardening; 2) Growth analysis and chemical analysis can be used for characterizing behavioural differences due to daylength.

From this study it can be concluded that red clover varieties and local strains originating from different latitudes $\left(60-66^{\circ} \mathrm{N}\right)$ all behaved as late flowering, one-cut types. However, differences could be detected
Table 16. Proline content (mg/g DM) of the roots of red clover varieties (V) grown at 12,16 and $20 \mathrm{~h}$ daylengths (D) and hardened after the sccond cut for four weeks at $+4^{\circ} \mathrm{C}$ temperature and $8 \mathrm{~h}$ daylength.

\begin{tabular}{|c|c|c|c|c|}
\hline \multirow[t]{2}{*}{ Variety (V) } & \multicolumn{4}{|c|}{ Daylength (D) } \\
\hline & $12 \mathrm{~h}$ & $16 \mathrm{~h}$ & $20 \mathrm{~h}$ & Avg. \\
\hline Venla & $.284 \mathrm{c}$ & $.298 b c$ & $.600 \mathrm{c}$ & $.394 d$ \\
\hline Jokioinen & $.226 a$ & $.352 \mathrm{de}$ & $.472 \mathrm{~b}$ & $.350 \mathrm{~b}$ \\
\hline Björn & $.278 \mathrm{c}$ & $.234 \mathrm{a}$ & $.516 c$ & $.343 b$ \\
\hline Bjursele & $.318 \mathrm{~d}$ & $.268 \mathrm{~b}$ & $.758 \mathrm{f}$ & $.448 \mathrm{e}$ \\
\hline Tepa & $.374 \mathrm{e}$ & $.314 c$ & $.356 a$ & $.348 b$ \\
\hline Vilo & $.284 \mathrm{c}$ & $.294 b c$ & $.746 \mathrm{f}$ & $.441 \mathrm{e}$ \\
\hline Jylhả & $.270 b c$ & $.354 \mathrm{e}$ & $.478 \mathrm{~b}$ & $.367 \mathrm{c}$ \\
\hline Mustamăki & $.324 \mathrm{de}$ & $.474 \mathrm{f}$ & $.548 \mathrm{~d}$ & $.449 \mathrm{e}$ \\
\hline Airaksinen & $.240 \mathrm{ab}$ & $.322 \mathrm{~cd}$ & $.370 \mathrm{a}$ & $.311 a$ \\
\hline \multirow[t]{2}{*}{ Haapaniemi } & $.254 a b c$ & $.454 \mathrm{f}$ & $.606 \mathrm{e}$ & $.438 \mathrm{e}$ \\
\hline & $.285 \mathrm{~A}$ & $.336 \mathrm{~A}$ & $.545 \mathrm{~B}$ & .389 \\
\hline $\begin{aligned} & \text { D.05 } \mathrm{D} \\
& \mathrm{V} \\
& \mathrm{D} \times \mathrm{V}\end{aligned}$ & $\begin{array}{l}0,109 \\
0,015 \\
0,030\end{array}$ & & & \\
\hline
\end{tabular}

among the strains. The most distinct northern type was Bjursele. The most distinct southern Finnish type was strain Vilo originating from the latitude $61^{\circ} \mathrm{N}$. The rest of the strains possessed some northern and southern features. The most interesting strain was Jylhä from the latitude $64^{\circ} \mathrm{N}$ which displayed some strong northern behaviour together with southern features indicating that adaptation is incomplete.

The study showed that chemical methods can be used for the purposes of breeding in determining the adaptation of plants to various daylength conditions as well as the effects of daylength on the hardening and overwintering of plants.

\section{Literature}

Chinard, F.P. 1952. Photometric estimation of proline and ornithine. J. Biol. Chem. 199: 91-95.

COOPER, J.P. 1965. The evolution of forage grasses and legumes. In J.P. Hutcnison (ed.) Crop plant evolution, Cambridge, 142-165.
Evans, Alica M. 1976. Clovers. In. N.V. Simmons (ed.) Evolution of crops plants. New York, 175-179.

HawkINS, R.P. 1952. Investigations on local strains of herbage plants 2 . Types of red clover and their investigations. J. Brit. Grassl. Soc. 8: 213-238. 
Hiltunen, R., Huhtikangas, A. \& Hovinen, S. 1979. Breeding of a zero erucic spring turnip-rape cultivar. Brassica campestris L., adapted to Finnish climatic conditions. 1. The use of glass capillary column gas chromatography in fatty acid analysis. Acta Pharm. Fenn. 88: $31-34$.

Julén, G. 1959. Rotklee, Handbuch der Pflanzenzüchtung IV. p. 242-305. - 1977. Rödklövers dagslängdreaktion och dess betydelse för sorternas utbredningsområden. Sver. Utsădesf. Tidskr 87: 343-361.

KUIPER, P.J.C. 1970. Lipids in alfalfa leaves in relation to cold hardiness. Plant Physiol. 45: 684-686.

Leddet, C. \& Schaverbeke, J. 1975. Action de la proline sur la resistance au gel des tissues de Topinambour en survic. Acad. Sci. (Paris) 280: 2849-2852.

Pieters, A.J. 1928. The proper binomial or varietal trinomial for American Mammoth red clover.

RAVANTtI, S. 1961. Suomalaisesta puna-apilasta. Maatal. ja koetoim. 15: 174-183.

-1980 . Winter hardiness and yield of local varieties of Finnish red clover grown in southern Finland at the Anttila Experimental Farm of the Hankkija Plant Breeding Institute in 1962-63. Ann. Agric. Fenn. 19: $142-154$.

DE LA RoChe, I.A. 1979. Increase in linolenic acid is not a prequisite for development of freezing tolerance in wheat. Plant Physiol. 63: 5-8.

-, Andrews, C.J., Pomeroy, M.K., Weinberger, P. \& KATES, M. 1972. Lipid changes in winter wheat seedling (Triticum aestivum) at temperatures inducing cold hardiness. Can. J. Bot. 50: 2401-2409.

SCHulze, E. 1957. Photoperiodische Versuche an mehrjährigen Futterpflanzen. Z. Acker Pfl.bau 103:

\section{SELOSTUS}

\section{Puna-apilan sopeutuminen pitkään päivään}

\section{Seppo Pulli}

\section{Maatalouden tutkimuskeskus, kasvinjalostusosasto 31600 Jokioinen}

Maatalouden tutkimuskeskuksen kasvinviljelyosaston tutkimuksessa selvitettiin kasvihuoneessa viiden tunnetun puna-apilalajikkeen ja viiden puna-apilan paikalliskannan suhtautumista päivănpituuteen. Kasvien alkuperăt ja sopeutumisalueet kattoivat leveyspiirit $60-66^{\circ} \mathrm{N}$. Päivănpituudet tutkimusajanjaksona olivat 12,16 ja $20 \mathrm{~h}$, päivã/yölämpötilat $17^{\circ} / 14^{\circ}$ ja kasvatusvalojen intensiteetti 21.4 klux.

Kasvit niitettiin tutkimusajanjakson aikana kolme kertaa. Kussakin kasvuperiodissa määritettiin kukkimisen aikaisuus ja runsaus, kasvin pituuskasvu ja kasvien maanpäällisen osan kuiva-ainesato. Versojen ja lehtien lukumaaărä ja lehtiala sekă yksityinen lehdenkoko määritet-
198-216.

Sмıтн, D. 1969. Removing and analyzing total nonstructural carbohydrates from plant tissue. Wisconsin Agr. Exp. Sta. Res. Rep. 41.

Stewart, C.R. 1980. The mechanism of abscisic acidinduced proline accumulation in barley leaves. Plant Physiol. 66: 230-233.

- 1981. Proline accumulation: biochemical aspects in: The physiology and biochemistry of drought resistance in plants. (L.G. Paley and D. Aspinall eds.). Academic Press p. 243-253.

TANASCH, L. 1979. Untersuchnungen über die photoperiodische Reaktion des Rotklee (Trifolium pratense L.) I. Einfluß der Tageslänge auf die Ertragsmerkmale. Bodenkultur 30: 181-196.

UMAERUS, M. 1963a. The influence of photoperiod treatment on the overwintering of red clover. Z. Pfl. Zücht. 50: $167-193$.

- 1963b. Chemical composition, flowering and morphological development of red clover under photoperiodic treatments at different latitudes. Acta Agric. Scand. 13: 17-64.

Valle, O. \& Carrison, C.S. 1959. Seed production of Finnish single-cut Tammisto red clover at different latitudes and the influence of these environmental conditions on varietal performance. Ann. Acad. Sci. Fenn. A. 45: $1-20$.

Willemot, C. 1977. Simultaneous inhibition of linolenic acid synthesis in winter wheat roots and frost hardening by BASF 13-338, a derivate of pyridazinone. Plant Physiol. 60: 1-4.

Williams, R.D. 1927. Red clover investigations 1919-26. Welsh Pl. Breed. Sta. Bull. H. 7: 1-136.

tiin toisessa niitossa sekä juuren koko kolmannessa niitossa. Toisen niiton jälkeen osa materiaalista vietiin keinolliseen karaistumiseen 26 päivăksi. Keinollinen karaistuminen sisălsi $+4^{\circ} \mathrm{C}$ lämpötilan, $8 \mathrm{~h}$ päivänpituuden ja 10 klux valovoimakkuuden. Karaistumisefektin selvittămiseksi kasvien juurista mäăritettiin talvehtimisen vararavinnot, pitkăketjuiset rasvahapot ja proliini.

Tutkimus osoitti, ettả kasvien sopeutuminen tiettyyn päivănpituuteen heijastuu voimakkaasti sen kasvuun, kehitykseen ja talvenkeståvyden kehittymiseen. Puna-apilalla päivänpituus nãytteli merkittãväă osaa sopeutumisprosessissa ja tulisi ottaa tăysipainoisesti huomioon jalostustyössă. 